\title{
An Approach to Removing Large Quantities of Atmospheric Greenhouse Gases
}

\author{
John B. Cook ${ }^{1}$, Svetlana R. Amirova ${ }^{2}$, Edwin A. Roehl Jr. ${ }^{1}$, Paul A. Comet $^{3}$, Tamara V. Tulaykova ${ }^{4}$ \\ ${ }^{1}$ Advanced Data Mining International, Greenville, S.C, USA \\ ${ }^{2}$ Brody School of Medicine, East Carolina University, Greenville, North Carolina, USA \\ ${ }^{3}$ Comet Environmental Consulting, Houston, Texas, USA \\ ${ }^{4}$ Wave Research Center at A. M. Prokhorov's General Physics Institute, Moscow, Russia
}

\section{Email address:}

john.cook@advdmi.com (J. B. Cook), tulaikova@gmail.com (T. V. Tulaykova), ed.roehl@advdmi.com (Edwin A. R. Jr.), pcomet@prodigy.net (P. A. Comet), amirova.svetlana@yahoo.com (S. R. Amirova)

\section{To cite this article:}

John B. Cook, Svetlana R. Amirova, Edwin A. Roehl Jr., Paul A. Comet, Tamara V. Tulaykova. An Approach to Removing Large Quantities of Atmospheric Greenhouse Gases. American Journal of Environmental Protection. Special Issue: New Technologies and Geoengineering Approaches for Climate. Vol. 5, No. 3-1, 2016, pp. 21-25. doi: 10.11648/j.ajep.s.2016050301.14

Received: March 24, 2016; Accepted: March 27, 2016; Published: May 10, 2016

\begin{abstract}
A method for removing atmospheric carbon dioxide $\left(\mathrm{CO}_{2}\right)$ and water vapor is proposed. The method sprays clouds with alkaline compounds to significantly increase the solubility of $\mathrm{CO}_{2}$ in the cloud water, providing for much higher than normal levels of $\mathrm{CO}_{2}$ to be absorbed by rain droplets. The $\mathrm{CO}_{2}$ is transported to the ground for sequestration in surface and/or ground water, and available for carbon fixation by plants and organisms. Presented calculations estimate that 38 gigatonnes of atmospheric $\mathrm{CO}_{2}$ could be removed per year by applying the process over $0.08 \%$ to $2.4 \%$ of the Earth's surface. Laboratory experiments that grew multiple edible plant species irrigated with the modified rainwater indicated yield benefits. A concept for removing atmospheric methane $\left(\mathrm{CH}_{4}\right)$ is also presented. Powerful lasers would ionize the $\mathrm{CH}_{4}$ to form $\mathrm{CO}_{2}$ that could then be removed by the alkaline-enhanced rainfall method.
\end{abstract}

Keywords: Climate Change, Greenhouse Gas, Carbon Dioxide, Methane, Water Vapor, Removal, Alkali, pH Adjustment, Precipitation, Cloud Seeding, Laser

\section{Introduction}

Current global emissions of greenhouse gases are exceeding the Earth's assimilative capacity, causing them to accumulate in the atmosphere [1], [2]. Water vapor comprises $95 \%$ of all greenhouse gases [3], however, carbon dioxide $\left(\mathrm{CO}_{2}\right)$ and methane $\left(\mathrm{CH}_{4}\right)$ are of greater concern. Higher greenhouse gas concentrations are widely believed to contribute to climate change, extreme weather events, rising sea levels, and other marked changes, such as the acidification of surface waters and soils.

Over the past century the carbon dioxide $\left(\mathrm{CO}_{2}\right)$ concentration rose from 280 to 400 parts per million (ppm), the methane $\left(\mathrm{CH}_{4}\right)$ concentration rose from 0.9 to $1.8 \mathrm{ppm}$, and both continue to rise rapidly [4], [5]. The oceans' natural alkalinity allows them to store a large amount of $\mathrm{CO}_{2}$, including more than a quarter of that produced anthropogenic ally. This has increased ocean acidity $\sim 26 \%$ from preindustrial levels, which corresponds to a decrease in $\mathrm{pH}$ from an average of 8.2 to 8.1 , or less. A further decrease of $\sim 0.3$ units by 2100 is likely unless $\mathrm{CO}_{2}$ emissions are reduced rapidly. Higher ocean acidity negatively impacts marine ecosystems and the economic benefits they provide [6], [7]. Similarly, rains in industrial regions since the mid-20th century have caused soil deterioration due to higher acidity, with current $\mathrm{pH} \approx 3-4$ [8], reducing alkalinity in the environment.

The development of methods that can efficiently remove greenhouse gases already in the atmosphere would be beneficial. Precipitation enhancement methods, which de facto remove water vapor, have been developed primarily for agriculture, water supply, and reducing air pollution [9], [10]. Typically, aircraft, rockets, or other projectiles are used to disperse hygroscopic or glacial particles to alter cloud microstructure, inducing precipitation [11], [12]. Seeding 
along a narrow flight path can be sufficient to restructure an entire cloud. Acoustic wave generators have been investigated as an alternative means to inducing precipitation [13], [14].

A new method proposed here expands the purpose of precipitation enhancement to include climate modification through the removal of large amounts of under-cloud $\mathrm{CO}_{2}$. The solubility of $\mathrm{CO}_{2}$ in water is highly sensitive to $\mathrm{pH}$ [15], [16], so the first step is to disperse an alkaline compound such as potassium hydroxide $(\mathrm{KOH})$ inside clouds over selected areas to increase the $\mathrm{pH}$ of the clouds' constituent microscopic water droplets to $10-11$. The alkaline particles should be consistent in size and composition, and dispersed uniformly inside clouds to produce droplets formed by nucleating water vapor which are uniform in size and $\mathrm{pH}$.

The method's second step is to induce rain, allowing the high $\mathrm{pH}$ rain to absorb substantially more $\mathrm{CO}_{2}$ than a normal $\mathrm{pH}$ rain or a two-dimensional (2-D) patch of surface water whose specific surface area is less than rain's three-dimensional (3-D) droplets. The second step would be unnecessary if alkalis having strong hygroscopic properties are used. Once on the ground, the dissolved $\mathrm{CO}_{2}$ is sequestered in surface and/or ground water, and available for carbon fixation by plants and organisms.

Below are calculations that estimate the efficiency of the proposed method for atmospheric $\mathrm{CO}_{2}$ removal, and results from laboratory experiments that grew different crop species irrigated with the modified rainwater. Also described is a concept that uses laser-induced oxidation to convert atmospheric $\mathrm{CH}_{4}$ into $\mathrm{CO}_{2}$ that can then be removed by the alkaline-enhanced rainfall method.

\section{Atmospheric $\mathrm{CO}_{2}$ Removal}

The typical $\mathrm{pH}$ of normal rainwater ranges from 5.6 to a neutral 7.0, at which the concentrations of dissociated ions are relatively small. The insoluble and dissociated portions of the weak acid that remains after attaining the equilibrium of saturation for water by $\mathrm{CO}_{2}$ are described by (1), where $\mathrm{H}_{2} \mathrm{CO}_{3}$ is carbonic acid, $\mathrm{H}^{+}$is hydrogen ion to determine $\mathrm{pH}$, and $\mathrm{HCO}_{3}{ }^{-}$and $\mathrm{CO}_{3}{ }^{2-}$ are bicarbonate and carbonate ions.

$$
\begin{gathered}
\mathrm{CO}_{2}+\mathrm{H}_{2} \mathrm{O}=\mathrm{H}_{2} \mathrm{CO}_{3} \\
\mathrm{H}_{2} \mathrm{CO}_{3}=\mathrm{HCO}_{3}{ }^{-}+\mathrm{H}^{+} \\
\mathrm{HCO}_{3}{ }^{-}=\mathrm{CO}_{3}{ }^{2-}+\mathrm{H}^{+}
\end{gathered}
$$

The equilibrium concentrations of $\mathrm{H}_{2} \mathrm{CO}_{3}, \mathrm{HCO}_{3}{ }^{-}$, and $\mathrm{CO}_{3}{ }^{2-}$ at a neutral $\mathrm{pH}=7.0$ are approximately $0.71,3.3$, and 0.001 milligrams per liter $(\mathrm{mg} / \mathrm{l})$, respectively [17]. $\mathrm{CO}_{2}$ solubility increases as $\mathrm{pH}$ increases due to an increasing $\mathrm{H}^{+}$ concentration, with $\mathrm{HCO}_{3}{ }^{-}$and $\mathrm{CO}_{3}{ }^{2-}$ concentrations increasing by one and two orders of magnitude, respectively, for each unit change in $\mathrm{pH}$. The fractions of carbon in the molar masses of $\mathrm{H}_{2} \mathrm{CO}_{3}, \mathrm{HCO}_{3}{ }^{-}$, and $\mathrm{CO}_{3}{ }^{2-}$ are $0.1935,0.1967$, and 0.2 , respectively, so all fractions are equal to or approximately equal to 0.2 .

The mass of carbon $\mathrm{M}_{\mathrm{C}}(\mathrm{pH})$ in the dissolved $\mathrm{CO}_{2}$ in a rainfall volume equivalent $U_{w}=h_{w} A$ is estimated from (2), where $\mathrm{h}_{\mathrm{w}}$ and $\mathrm{A}$ are the volume's height and cross-sectional area. For brevity, the $\mathrm{H}_{2} \mathrm{CO}_{3}, \mathrm{HCO}_{3}{ }^{-}$, and $\mathrm{CO}_{3}{ }^{2}$ concentrations are referred to as $\mathrm{C}_{1}, \mathrm{C}_{2}(\mathrm{pH})$, and $\mathrm{C}_{3}(\mathrm{pH})$.

$$
\mathrm{M}_{\mathrm{C}}(\mathrm{pH}) \approx \mathrm{U}_{\mathrm{w}}\left\{0.2\left[\mathrm{C}_{1}+\mathrm{C}_{2}(\mathrm{pH})+\mathrm{C}_{3}(\mathrm{pH})\right]\right\}
$$

The concentration of atmospheric carbon $\mathrm{C}_{\mathrm{a}-}$ in an air volume with a height $\mathrm{h}$ and a unit $\left(1 \mathrm{~m}^{2}\right)$ cross-section can be estimated from (3), which is derived from (2). The vertical mixing ratio of $\mathrm{CO}_{2}$ is estimated to be constant for altitudes of interest. The fraction of carbon in the molar mass of $\mathrm{CO}_{2}$ is $12 / 44=0.27$. For a cloud at an altitude of $1 \mathrm{~km}$, the cloud water $\mathrm{pH}$ should be increased from a typical 5.6 to 10.3 for complete $\mathrm{CO}_{2}$ removal $\left(\mathrm{C}_{\mathrm{a}-}=420 \mathrm{ppm}\right)$.

$$
\mathrm{C}_{\mathrm{a}-} \approx\left(\mathrm{h}_{\mathrm{w}} / \mathrm{h}\right)\left[0.2\left(\mathrm{C}_{1}+\mathrm{C}_{2}(\mathrm{pH})+\mathrm{C}_{3}(\mathrm{pH})\right] / 0.27\right.
$$

The deployment of $\mathrm{KOH}$ in a liquid water aerosol is used to illustrate how to estimate the amount of an alkali needed to raise the $\mathrm{pH}$ of cloud water to an effective level. The dissociation reaction of $\mathrm{KOH}$ in water represented by (4) indicates that the molar concentrations of $\mathrm{KOH}$ and $\mathrm{OH}^{-}$are equal.

An alkali facilitates the dissociation of ionic species in water according to the constant $\mathrm{K}_{\mathrm{w}}=10^{-14}$ at $20^{\circ} \mathrm{C}$ [17]. According to (4) and (5), the $\mathrm{KOH}$ mass concentration $\mathrm{n}_{\mathrm{KOH}}$ needed to raise the $\mathrm{pH}$ of the cloud water from 5.6 to 10 is $10^{-4}$ $\mathrm{mol} / 1$, or $56 \times 10^{-4} \mathrm{~g} / 1$ when converted to a molar mass. For an example $1 \mathrm{~km}^{3}$ cloud having a liquid water concentration of 1 $\mathrm{g} / \mathrm{m}^{3}$, the mass of $\mathrm{KOH}$ to be dispersed would only be $5.6 \mathrm{~kg}$. Note that little of the $\mathrm{KOH}$ would be spent within the cloud over a short period prior to rainfall inducement due to the small resident concentration of $\mathrm{CO}_{2}$ molecules ( $\left.400 \mathrm{ppm}\right)$.

$$
\begin{gathered}
\mathrm{KOH}=\mathrm{K}^{+}+\mathrm{OH}^{-} \\
\mathrm{H}^{+}+\mathrm{OH}^{-}=\mathrm{H}_{2} \mathrm{O}, \mathrm{K}_{\mathrm{w}}=\left[\mathrm{H}^{+}\right]\left[\mathrm{OH}^{-}\right]
\end{gathered}
$$

The volume of water precipitated by a cloud $U_{I}$ is estimated by (6), where I is the rainfall rate, $\mathrm{A}_{\mathrm{s}}$ is the 2-D receiving area on the Earth' surface, and $\mathrm{T}$ is the duration of the rainfall event. The number of spherical droplets $N$ having a radius $r_{d}$ in $U_{I}$ and the droplets' total surface area $A_{d}$ are estimated by (7) and (8) respectively.

$$
\begin{gathered}
\mathrm{U}_{\mathrm{I}}=\mathrm{I} \mathrm{A}_{\mathrm{s}} \mathrm{T} \\
\mathrm{N}=3 \mathrm{U}_{\mathrm{I}} /\left(4 \pi \mathrm{r}_{\mathrm{d}}^{3}\right) \\
\mathrm{A}_{\mathrm{d}}=\mathrm{N} \times 4 \pi \mathrm{r}_{\mathrm{d}}^{2}
\end{gathered}
$$

If given a moderate rainfall characterized by $\mathrm{A}_{\mathrm{s}}=1 \mathrm{~km}^{2}=$ $10^{6} \mathrm{~m}^{2}, \mathrm{I}=6 \mathrm{~mm} / \mathrm{h}, \mathrm{T}=1$ hour, and $\mathrm{r}_{\mathrm{d}}=0.5 \mathrm{~mm}$, then $\mathrm{U}_{\mathrm{I}}=$ $6,000 \mathrm{~m}^{3}, \mathrm{~N}=10^{13}$, and $\mathrm{A}_{\mathrm{d}}=3.6 \times 10^{7} \mathrm{~m}^{2}=36 \times \mathrm{A}_{\mathrm{s}}$. Alternatively, the Marshall-Palmer approximation accurately estimates droplet radii spectra for drizzle, rain, or storm events, and can be applied to perform more detailed droplet surface area estimates [18], [19]. The parameters and measurement methods used to characterize precipitation inside clouds and atmosphere volumes are described in [20]-[22]. 
Rapid $\mathrm{CO}_{2}$ saturation of droplets is made possible by their small size and slow speeds. The terminal speed of a droplet $V_{g}$ is estimated by (9) by equating the forces of gravity and air resistance, where $\rho_{\mathrm{a}}$ and $\rho_{\mathrm{w}}$ are the densities of air and water respectively, and $\mathrm{g}$ is the acceleration due to gravity. A droplet having $\mathrm{r}_{\mathrm{d}}=0.5 \mathrm{~mm}$ falling from an altitude $\mathrm{h}=1 \mathrm{~km}$ has a $\mathrm{V}_{\mathrm{g}}=$ $2.9 \mathrm{~m} / \mathrm{sec}\left(\rho_{\mathrm{a}}=1.2 \mathrm{~kg} / \mathrm{m}^{3}\right.$ at $\left.12^{\circ} \mathrm{C}\right)$. The travel time $\mathrm{t}_{\mathrm{h}}=350$ seconds is estimated by (10).

$$
\begin{gathered}
\mathrm{V}_{\mathrm{g}}=\left(2 \mathrm{r}_{\mathrm{d}} \mathrm{g} \rho_{\mathrm{w}} / \rho_{\mathrm{a}}\right)^{1 / 2} \\
\mathrm{t}_{\mathrm{h}}=\mathrm{h} / \mathrm{V}_{\mathrm{g}}
\end{gathered}
$$

The time $t_{a w}$ needed for a droplet to become saturated with $\mathrm{CO}_{2}$ depends on the ratio of the droplet's aerated volume to its surface area, and is estimated by (11), where $\mathrm{k}_{\mathrm{aw}}$ is a measured constant, called the gas transfer velocity, for air and water [23]-[26]. For $\mathrm{k}_{\mathrm{aw}} \approx 0.5 \times 10^{-4} \mathrm{~m} / \mathrm{sec}$ and $\mathrm{r}_{\mathrm{d}}=0.5 \mathrm{~mm}, \mathrm{t}_{\mathrm{aw}}=6$ seconds, indicating that the much longer travel time $t_{h} \approx 350$ seconds is sufficient for nearly complete removal of under-cloud $\mathrm{CO}_{2}$ molecules.

$$
\mathrm{t}_{\mathrm{aw}}=\mathrm{r}_{\mathrm{d}} / 3 \mathrm{k}_{\mathrm{aw}}
$$

\subsection{Impact on Plants}

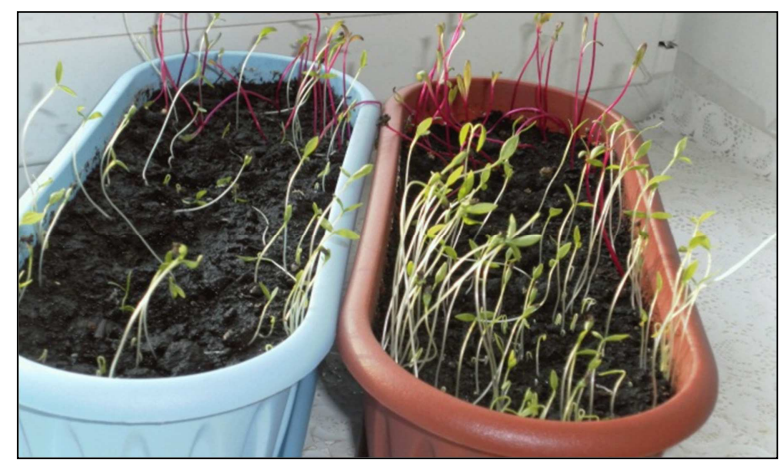

a

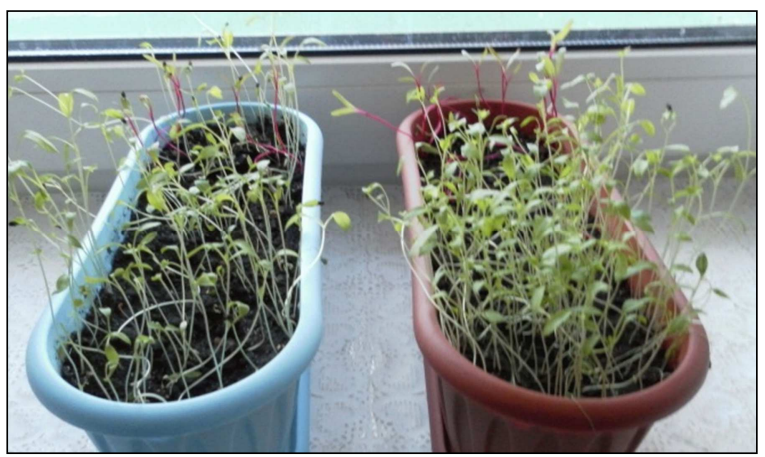

b

Fig. 1. First crop plants after 19 days (a) and 31 days (b) days. The blue pot (left) was irrigated daily with distilled water. The brown pot (right) was irrigated with an alkaline solution.

A potential benefit to plant growth is illustrated by results from indoor bench-scale experiments [27] in which two simulated crops were irrigated with and without alkaline-enhanced water for a period of one month (Figs. 1 and 2). The blue pots were irrigated daily with distilled water, and the brown pots were irrigated using the same regime with a stable $\mathrm{KOH}$-distilled water solution having a $\mathrm{pH}=12$. For the first crop both pots were identically planted with beetroots (10 grains), carrots (20 grains), and parsley (2 grams). For the second crop the pots were planted with dill (20 grains) and cucumber (5 grains). As shown, both crops responded favorably to the alkaline-enhanceme irrigation.

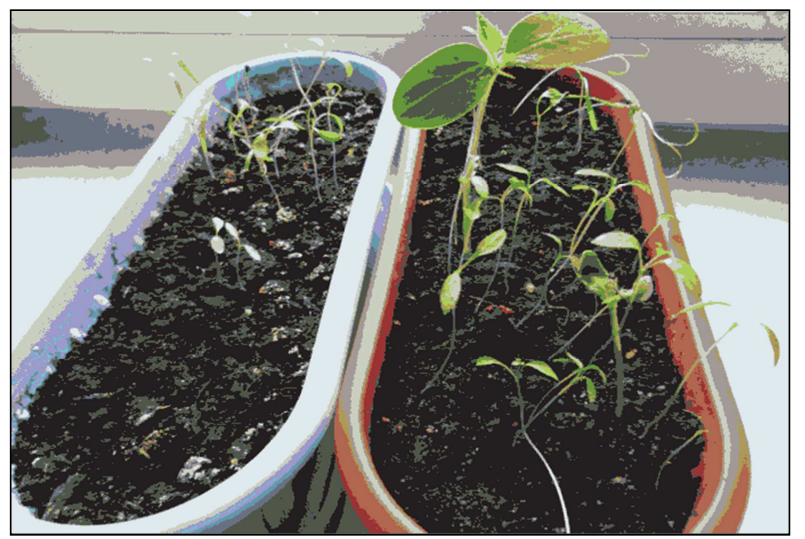

Fig. 2. Second crop plants after 19 days.

\subsection{Global Application}

Table 1. Estimated Outcomes of Global Application.

\begin{tabular}{lllll}
\hline $\mathbf{p H}$ & $\mathbf{5 . 6}$ & $\mathbf{1 0}$ & $\mathbf{1 0 . 5}$ & $\mathbf{1 1}$ \\
\hline $\mathrm{M}_{\mathrm{C}}{ }^{1}\left(\mathrm{~kg} / \mathrm{m}^{2}\right)$ & $1.6 \times 10^{-4}$ & 0.849 & 4.05 & 26.5 \\
$\mathrm{M}^{\mathrm{A}}(\mathrm{kg})$ & $8.2 \times 10^{10}$ & $4.3 \times 10^{14}$ & $2.1 \times 10^{15}$ & $1.4 \times 10^{16}$ \\
$\mathrm{M}^{\mathrm{A}}{ }_{\mathrm{CO} 2}(\mathrm{~kg})$ & $3 \times 10^{11}$ & $1.6 \times 10^{15}$ & $7.7 \times 10^{15}$ & $5 \times 10^{16}$ \\
$\mathrm{~A}_{\mathrm{p}}(\%)$ & - & 2.4 & 0.5 & 0.08 \\
$\mathrm{Q}_{\text {КОН }}(\mathrm{kg})$ & - & $6.9 \times 10^{10}$ & $4.8 \times 10^{10}$ & $2.3 \times 10^{10}$ \\
\hline
\end{tabular}

$\mathrm{pH}=\mathrm{pH}$ of induced rainfall, $\mathrm{M}_{\mathrm{C}}{ }^{1}=$ mass of atmospheric carbon removed by 1 meter of rainfall per $\mathrm{m}^{2}$ of the Earth's surface, $\mathrm{M}_{\mathrm{C}}^{\mathrm{A}}=$ mass of global atmospheric carbon removed, $\mathrm{M}^{\mathrm{A}}{ }_{\mathrm{C} 02}=$ mass of global $\mathrm{CO}_{2}$ removed, $\mathrm{A}_{\mathrm{p}}=$ percentage of the Earth's surface area needed to completely remove annual global $\mathrm{CO}_{2}$ emissions $\left(\mathrm{E}_{\mathrm{A}}\right)$, and $\mathrm{Q}_{\mathrm{KOH}}=$ mass of $\mathrm{KOH}$ needed to remove $\mathrm{E}_{\mathrm{A}}$ each year.

Table 1 provides statistics that estimate outcomes of applying the method globally. The Earth's surface area $A_{E}=$ $5.1 \times 10^{8} \mathrm{~km}^{2}$, the average global annual rainfall $\mathrm{h}_{\mathrm{A}}=1 \mathrm{~m} \mathrm{[28]}$, and the annual global $\mathrm{CO}_{2}$ emissions $\mathrm{E}_{\mathrm{A}} \approx 3.8 \times 10^{13} \mathrm{~kg}[29]$. Using (2), row 2 gives the masses of atmospheric carbon $\mathrm{M}_{\mathrm{C}}{ }^{1}$ removed by 1 meter of annual rainfall per $\mathrm{m}^{2}$ of the Earth's surface at the different $\mathrm{pH}$ levels shown in row 1. Row 3 gives the global masses of carbon removed $\mathrm{M}^{\mathrm{A}}{ }_{\mathrm{C}}$ per (12). Row 4 gives the global masses of $\mathrm{CO}_{2}$ removed $\mathrm{M}^{\mathrm{A}}{ }_{\mathrm{C} 02}$ per (13), 0.27 being the carbon ratio of $\mathrm{CO}_{2}$. Using (14), row 5 gives the percentages $A_{p}$ of $A_{E}$ needed to completely remove annual emissions $E_{A}$, indicating the need is $0.08 \%-2.4 \%$. Row 6 gives the mass $\mathrm{Q}_{\mathrm{KOH}}$ of $\mathrm{KOH}$ needed to remove $\mathrm{E}_{\mathrm{A}}$ each year per (15), indicating that the amount needed is a fraction of the $19 \times 10^{10} \mathrm{~kg}$ of nitrogen, phosphorous, and potassium $(\mathrm{N} / \mathrm{P} / \mathrm{K})$ fertilizers used globally in 2014 [30]. 


$$
\begin{gathered}
\mathrm{M}_{\mathrm{C}}^{\mathrm{A}}=\mathrm{M}_{\mathrm{C}}{ }^{1} \mathrm{~A}_{\mathrm{E}} \\
\mathrm{M}_{\mathrm{C} 02}^{\mathrm{A}}=\mathrm{M}_{\mathrm{C}}^{\mathrm{A}} / 0.27 \\
\mathrm{~A}_{\mathrm{p}}=100 \times \mathrm{E}_{\mathrm{A}} / \mathrm{M}^{\mathrm{A}} \mathrm{C} 02 \\
\mathrm{Q}_{\mathrm{KOH}}=\mathrm{n}_{\mathrm{KOH}} \mathrm{h}_{\mathrm{A}} \mathrm{A}_{\mathrm{E}} \mathrm{A}_{\mathrm{p}}
\end{gathered}
$$

\section{Atmospheric $\mathrm{CH}_{4}$ Removal}

A concept is also proposed that would use lasers to enhance the conversion of atmospheric $\mathrm{CH}_{4}$ into $\mathrm{CO}_{2}$ and water, a process that occurs naturally through the photo-dissociation of $\mathrm{CH}_{4}$ molecules by sunlight [31]. Once freed, the carbon ions bond preferentially with oxygen [32]. This process can be stimulated by using a powerful laser with an optimized wavelength. Subsequent alkaline-enhanced rainfall would remove the $\mathrm{CO}_{2}$.

Measurements of atmospheric $\mathrm{CH}_{4}$ concentrations can be performed at distances of $8-11 \mathrm{~km}$ using pulsed integrated-path differential absorption Lidar in the infrared spectrum at wavelengths $\lambda=1,650$ nanometers (nm) [33], [34]; however, the photon energies are too low for ionization. For efficient ionization, the laser wavelength should coincide with a peak absorption frequency at the molecule's $\mathrm{C}-\mathrm{H}$ bond dissociation energy of $\mathrm{E} \approx 4.3 \mathrm{eV}$ electronvolts $(\mathrm{eV})$ or $\lambda=288$ $\mathrm{nm}$ due to the Planck-Einstein relation $\lambda E=h c=1240 \mathrm{eV}-$ $\mathrm{nm}$, where $\mathrm{h}$ is the Planck constant and $\mathrm{c}$ is the speed of light [35]. However, at UV irradiation other gases such as oxygen and nitrogen also could be ionized. Alternatively, multiple-photon excitation achieves photo-dissociation using a laser to bombard gas molecules with multiple photons, increasing their vibrational energy until their chemical bonds are broken [36]. $\mathrm{CH}_{4}$ has a small absorption peak near $\lambda=865 \mathrm{~nm}(1.43 \mathrm{eV})$ [37], suggesting that three or four photons could be sufficient for dissociation to occur.

\section{Conclusions}

A proposed approach could be effective at removing significant amounts of the main greenhouse gases of concern, i.e., water vapor, $\mathrm{CO}_{2}$, and $\mathrm{CH}_{4}$. Estimates show that a method for alkaline-enhanced rainfall could remove more than the $\sim 38$ gigatonnes of anthropogenic $\mathrm{CO}_{2}$ emitted each year if applied over a small portion of Earth's surface. The next step would be to field test the method's efficacy. An adjunct method for pre-treating atmospheric $\mathrm{CH}_{4}$ by laser is also proposed. It would convert the $\mathrm{CH}_{4}$ into $\mathrm{CO}_{2}$ for subsequent removal by alkaline-enhanced rainfall.

\section{Acknowledgements}

The authors thank Dr. Yakov Ponurovskii and Dr. Imant Vinorgadov for sharing information about monitoring greenhouse gases with tunable diode laser spectroscopy and the photo-dissociation of methane with lasers.

\section{References}

[1] IPCC, Contribution of Working Group III to the Fifth Assessment Report of the Intergovernmental Panel on Climate Change. Summary for Policymakers, Cambridge University Press, New York, 2014.

[2] Kleidon, A., Malhi, Y. and Cox, P. M., "Maximum entropy production in environmental and ecological systems introduction," Philos. Trans. R. Soc. B 365, 1297-1302. 2010.

[3] Freidenreich, S. M. and Ramaswamy, V., "Solar radiation absorption by carbon dioxide, overlap with water, and a parameterization for general circulation models," J. of Geophys. Res. 98, 7255-7264. 1993.

[4] Latest reading, Mauna Loa Observatory. 2016. https://scripps.ucsd.edu/programs/keelingcurve/. [Accessed Apr. 4, 2016].

[5] Schmidt, G., "Methane: a scientific journey from obscurity to climate super-stardom," NASA Goddard Space Center, 2004. http://www.giss.nasa.gov/research/features/200409_methane/. [Accessed Apr. 4, 2016].

[6] Andersson, A. J. and Gledhill, D., "Ocean acidification and coral reefs: effects on breakdown, dissolution, and net ecosystem calcification,” Annu Rev Mar Sci 5, 1.1-1.28, 2013.

[7] Secretariat of the Convention on Biological Diversity, Roberts, J. M. and Williamson, P. - ed., An Updated Synthesis of the Impacts of Ocean Acidification on Marine Biodiversity, Technical Series No. 75, Montreal, Canada, 2014.

[8] Izrael, Y. A. et al., Acid rain (Hydrometeoisdat, Russia, 1989).

[9] Langmuir, I., "Improved methods of conditioning surfaces for adsorption” J. Am. Chem. Soc. 59. 1762-1763. 1937.

[10] Dennis, A. S., Weather modification by cloud seeding, Academic Press, New York, 1980.

[11] Shmeter, S. M. and Berynlev, G. P., "Efficiency of cloud and precipitation modification with hygroscopic aerosols," Meteorology and Hydrology Rus., 2. 43-60. 2005.

[12] Tulaikova, T., Mihtchenko, A. and Amirova, S., "Micro physical model for glaciogenic particles in clouds for precipitation enhancement," Am. J. Env. Protection, 5(3-1). 10-14. 2016.

[13] Tulaikova, T. et al., Acoustic rains, Physmathbook, Moscow, 2010.

[14] Claus R. O. and Tulaikova, T. V., "New methods for helicopter for free flight inside clouds and precipitation enhancement," Am. J. Env. Protection, 5. 1-9. 2016.

[15] Yunge, H., Chemical compounds and radio-activity in the atmosphere, Clarendon, Oxford, 1965.

[16] Rasool, S. I. (ed.), Chemistry of the lower atmosphere, Plenum, New York, 1973.

[17] Sillen, L. G. (ed.), Stability constants of metal-ion complexes, Chemical Society, London, 1964.

[18] Borovikov, A. M., Physics of clouds, Hydromet-Press, Leningrad, Russia, 1961. 
[19] Kobayashi, S. T. et al, "Backscattering enhancement on spheroid-shaped hydrometeors: considerations in water and ice particles of uniform size and Marshall-Palmer distributed rains," Radio Science, 42. Apr.2007.

[20] Bruintjes, R. T., "A review of cloud seeding experiments to enhance precipitation and some new prospects," BAMS, 90. 805-820. 1999.

[21] Daly, C. et al, "Observation bias in daily precipitation measurements at United States cooperative network stations," BAMS 88. 899-912. 2007.

[22] Taylor, J. W. et al, "Aerosol measurements during COPE: composition, size and sources of CCN and IN at the interface between marine and terrestrial influences," Atmos. Chem. Phys. Discuss., doi: 10.5194/acp-2016-84, in review. 2016.

[23] Hoover, T. E., " $\mathrm{CO}_{2}$ exchange at the air-sea interface," J. Geoph.Res 74. 456-464. 1969.

[24] Liss, P. S., "Processes of gas exchange analysis an air-water interface," Deep-Sea Res. 20. 221-238. 1973.

[25] Broecher, H. C., "The influence of wind on $\mathrm{CO}_{2}$ exchange in a wind-water tunnel including the effect of minelayers," J. Mar. Res. 36. 595-610. 1978.

[26] Wanninkhof, R., "Chemical enhancement of $\mathrm{CO}_{2}$ exchange in natural water," Limnol. Oceanogr., 41. 689-687. 1996.

[27] Tulaikova, T., and Amirova, S., "The method for effective $\mathrm{CO}_{2}$ purification in the atmosphere," Global J. Sc. Frontier Res., 15-H (1). 1-9. 2015.

[28] Rees, G. and Rees, W., Physical principles of remote sensing, Cambridge University Press, 2013, 125.
[29] Olivier, J., Janssens-Maenhout, G., Muntean, M. and Peters, J., Trends in global $\mathrm{CO}_{2}$ emissions: 2015 report, PBL Netherlands Environmental Assessment Agency, 2015.

[30] Food and Agriculture Organization of the United Nations, "World fertilizer trends and outlook to 2018," Rome, Italy, 2015.

[31] Sheu, J., Mokheimer, E. and Ghoniem, A., "A review of solar methane reforming systems," Int. J. Hydrogen Energy, 40. 12929-12955. 2015.

[32] Clark, J., Calculations in AS/A Level Chemistry, Pearson Education, London, 2000.

[33] Dawsey, M. et al, "Optical parametric technology for methane measurements," Proc. 2015 SPIE, Lidar Remote Sensing for Environmental Monitoring XV, San Diego, USA.

[34] Riris, H. et al, "Airborne measurements of atmospheric methane column abundance using a pulsed integrated-path differential absorption Lidar," Applied Optics, 51 (34). 82968305. 2012.

[35] Schmidt, W., Optical spectroscopy in chemistry and life sciences, Wiley-VCH, Germany, 2005.

[36] Cantrell, C. D. (ed.), Multiple-photon excitation and dissociation of polyatomic molecules, Springer, New York, 1986.

[37] Brien, J. and Cao, H., "Absorption spectra and absorption coefficients for methane in the $750-940 \mathrm{~nm}$ region obtained by intracavity laser spectroscopy," J. Quant. Spec. Rad. Tran., 75 (3). 323-350. Oct. 2002. 